\title{
Isolation of New Aliphatic Sulfates and Sulfamate as the Daphnia Kairomones Inducing Morphological Change of a Phytoplankton Scenedesmus gutwinskii
}

\author{
Ko Yasumoto, ${ }^{a}$ Akinori Nishigami, ${ }^{a}$ Hiroaki Aor,${ }^{a}$ Chise Tsuchinashi, ${ }^{a}$ Fumie Kasai,${ }^{b}$ \\ Takenori Kusumi, ${ }^{a}$ and Takashi OoI ${ }^{*}, a$ \\ ${ }^{a}$ Institute of Health Biosciences, The University of Tokushima Graduate School; Tokushima, Tokushima 770-8505, Japan: \\ and ${ }^{b}$ National Institute for Environmental Studies; Onogawa, Tsukuba 305-8506, Japan. \\ Received October 4, 2007; accepted October 26, 2007; published online November 8, 2007
}

\begin{abstract}
New aliphatic sulfates and sulfamates were isolated from Daphnia pulex as the Daphnia kairomones that induced morphological defense of a freshwater phytoplankton Scenedesmus gutwinskii var. heterospina (NIES-802). Their structures were determined by spectroscopic and synthetic studies.
\end{abstract}

Key words Daphnia kairomone; Scenedesmus; aliphatic sulfate; aliphatic sulfamate

In a series of food chain in aquatic world, phytoplankton is the bottom creature that supports the lives of animals. It has been soundly believed that phytoplankton is docile and never resists against its fate. This belief has been disputed by Hessen and van Donk, who reported that a unicellular green alga, Scenedesmus subspicatus, achieved morphological change into 2-, 4-, and 8-coenobia (colonies) when the water in which a crustacean Daphnia magna, a grazer of the alga, had been cultured (Daphnia water) was added to the cultivation medium. ${ }^{1)}$ They also found that the grazing rate of the coenobium morph was lower than that of the unicellular morph, owing to the increased size of the former. This metamorphosis was supposed to be a self-defense mechanism acquired by the green alga and triggered by a kairomone secreted from $D$. magna. Their report has aroused the interest of many scientists to attempt to identify the kairomone, ${ }^{2-9)}$ Recently, we reported identification of the Daphnia kairomones that cause the morphological change in a unicellular green alga Scenedesmus gutwinskii var. heterospina (NIES-802) at $10^{-1}-10^{3} \mathrm{ng} / \mathrm{ml}$ concentrations. ${ }^{10,11)}$

Here we report isolation and structure determination of aliphatic sulfates and sulfamates $\mathbf{1 - 1 3}$ as the Daphnia kairomones, which are active at ng $-\mu \mathrm{g} / \mathrm{ml}$ concentration. To the best of our knowledge, compounds $\mathbf{1}-\mathbf{3}, \mathbf{5}-\mathbf{9}$ and $\mathbf{1 1}-$ 13 are new compounds. Their activity and structure correlation will be discussed elsewhere.

Frozen Daphnia $(10 \mathrm{~kg}$; Aso Tropical Fish Co., Ltd., Osaka) was soaked with methanol $(201 \times 3)$, and the methanol solution was evaporated, the residue being treated with water (91). The mixture was successively extracted with hexane, dichloromethane, and butanol, and the most active butanol extract was separated by HPLC monitoring the activity to afford $1(8.0 \mathrm{mg}), \mathbf{2}(0.5 \mathrm{mg}), \mathbf{3}(0.3 \mathrm{mg}), \mathbf{4}(3.8 \mathrm{mg}), \mathbf{5}$ $(0.5 \mathrm{mg}), \mathbf{6}(8.0 \mathrm{mg}), 7(0.4 \mathrm{mg}), \mathbf{8}(0.8 \mathrm{mg}) \mathbf{9}(0.6 \mathrm{mg}), \mathbf{1 0}$ $(1.5 \mathrm{mg}), \mathbf{1 1}(0.1 \mathrm{mg}), \mathbf{1 2}(0.2 \mathrm{mg})$, and $\mathbf{1 3}(1.5 \mathrm{mg})$.

The molecular formula of $\mathbf{1}$ was established as $\mathrm{C}_{9} \mathrm{H}_{19} \mathrm{O}_{4} \mathrm{~S}$ on the basis of HR-FAB-MS. The presence of a sulfate group was suggested by a fragment ion peak at $m / z 97\left(\mathrm{HSO}_{4}^{-}\right)$in the negative ion FAB-MS of $\mathbf{1}$. The ${ }^{1} \mathrm{H}-\mathrm{NMR}$ spectrum of $\mathbf{1}$ exhibited two methylene protons bearing a sulfate group at $\delta$ $4.03(2 \mathrm{H}, \mathrm{t}, J=6.6 \mathrm{~Hz} ; \mathrm{H}-1)$, two doublet methyls at $\delta 0.92$ $(6 \mathrm{H}, \mathrm{d}, J=6.6 \mathrm{~Hz} ; \mathrm{H}-8, \mathrm{Me}-7)$ and eleven methine/methylene protons at $\delta 1.68-1.23$. Interpretation of the ${ }^{1} \mathrm{H}-{ }^{1} \mathrm{H}$ COSY spectrum of 1 led to a gross structure as 7-methyloctyl sulfate. To rule out the possibility that isolated substance is less active and it might still be contaminated with a minute amount of highly active compound, compound $\mathbf{1}$ was synthesized. The Wittig olefination of adipic semialdehyde methyl ester (14) with isopropyltriphenylphosphonium iodide gave the methyl ester 15. Reduction of the double bond under $\mathrm{H}_{2}$ atmosphere over the $\mathrm{Pd}-\mathrm{C}$ catalyst followed by $\mathrm{LiAlH}_{4}$ re-

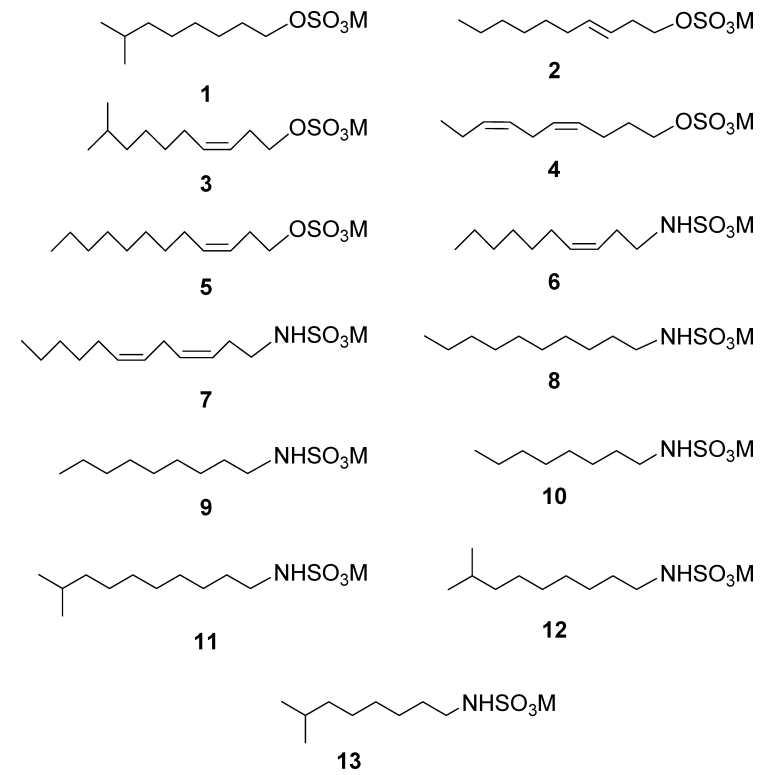

Fig. 1. The Structure of Daphnia Kairomones 1-13

The countercations were not identified and expressed as M.

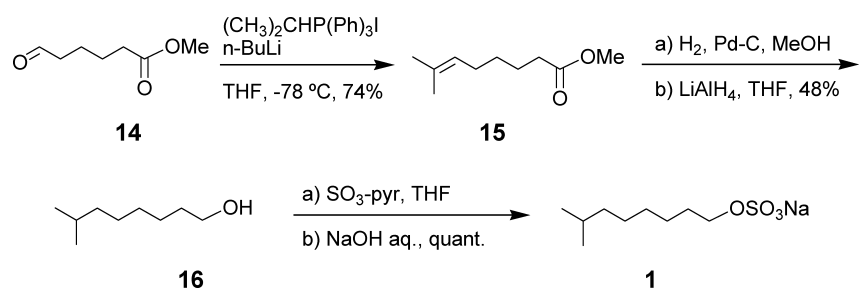

Chart 1. Synthesis of Compound $\mathbf{1}$ 
duction of the ester, provided 7-methyloctan-1-ol (16). The alcohol $\mathbf{1 6}$ was converted to the sulfate by treatment with pyridine- $\mathrm{SO}_{3}$ complex in tetrahydrofuran (THF) at room temperature to give the sulfate 1. Natural and synthetic sample of compound $\mathbf{1}$ possessed practically same activity.

The molecular formula of 2 was established as $\mathrm{C}_{10} \mathrm{H}_{19} \mathrm{O}_{4} \mathrm{~S}$ on the basis of HR-FAB-MS. The presence of a sulfate group was suggested by a fragment ion peak at $m / z 97\left(\mathrm{HSO}_{4}^{-}\right)$in the negative ion FAB-MS of 2. The ${ }^{1} \mathrm{H}-\mathrm{NMR}$ spectrum of $\mathbf{2}$ exhibited two olefinic protons at $\delta 5.59(1 \mathrm{H}, \mathrm{dtd}, J=\underline{15.2}$, $6.6,1.2 \mathrm{~Hz} ; \mathrm{H}-4)$ and $\delta 5.47(1 \mathrm{H}, \mathrm{dtd}, J=\underline{15.2}, 6.6,1.2 \mathrm{~Hz}$; H-3), two methylene protons bearing a sulfate group at $\delta$ $4.01(2 \mathrm{H}, \mathrm{t}, J=7.1 \mathrm{~Hz} ; \mathrm{H}-1)$, a methyl group at $\delta 0.94(3 \mathrm{H}, \mathrm{t}$, $J=7.1 \mathrm{~Hz} ; \mathrm{H}-10)$, and twelve methylene protons at $\delta 2.39$ 1.30. The ${ }^{1} \mathrm{H}-{ }^{1} \mathrm{H}$ COSY spectrum of the compound was consistent with the structure of 3-decenyl sulfate. The geometry of the double bonds in 2 was deduced to be $3 E$ from the underlined coupling constants of the olefinic protons.

The molecular formula of 3 was established as $\mathrm{C}_{11} \mathrm{H}_{21} \mathrm{O}_{4} \mathrm{~S}$ on the basis of HR-FAB-MS. The presence of a sulfate group was suggested by a fragment ion peak at $m / z 97\left(\mathrm{HSO}_{4}^{-}\right)$in the negative ion FAB-MS of 3. The ${ }^{1} \mathrm{H}-\mathrm{NMR}$ spectrum of $\mathbf{3}$ exhibited two olefinic protons at $\delta 5.52(1 \mathrm{H}, \mathrm{dt}, J=\underline{11.5}$, $7.1 \mathrm{~Hz} ; \mathrm{H}-4)$ and $5.44(1 \mathrm{H}, \mathrm{dt}, J=\underline{11.5}, 7.1 \mathrm{~Hz} ; \mathrm{H}-3)$, two methylene protons bearing a sulfate group at $\delta 4.00(2 \mathrm{H}, \mathrm{t}$, $J=7.2 \mathrm{~Hz} ; \mathrm{H}-1)$, two methyl groups at $\delta 0.92(6 \mathrm{H}, \mathrm{d}$, $J=6.6 \mathrm{~Hz} ; \mathrm{H}-10, \mathrm{Me}-9$ ) and 11 methine/methylene protons at $\delta 2.46-1.25$. The geometry of the double bonds in 3 was deduced to be $3 Z$ from the underlined coupling constants of the olefinic protons.

The molecular formula of $\mathbf{4}$ was established as $\mathrm{C}_{10} \mathrm{H}_{17} \mathrm{O}_{4} \mathrm{~S}$ on the basis of HR-FAB-MS. The presence of a sulfate group was suggested by a fragment ion peak at $m / z 97\left(\mathrm{HSO}_{4}^{-}\right)$in the negative ion FAB-MS of 4. The ${ }^{1} \mathrm{H}-\mathrm{NMR}$ spectrum of 4 exhibited four olefinic protons at $\delta 5.45-5.30(4 \mathrm{H}, \mathrm{m} ; \mathrm{H}-4$, $5,7,8)$, two methylene protons bearing a sulfate group at $\delta$ $4.04(2 \mathrm{H}, \mathrm{t}, J=6.6 \mathrm{~Hz} ; \mathrm{H}-1)$, a methyl group at $\delta 1.01(3 \mathrm{H}, \mathrm{t}$, $J=7.3 \mathrm{~Hz} ; \mathrm{H}-10$ ), and eight methylene protons at $\delta 2.85$ 1.76. The ${ }^{1} \mathrm{H}-{ }^{1} \mathrm{H}$ COSY spectrum of the compound was consistent with the structure of 4,7-decadienyl sulfate. The geometry of the two double bonds in $\mathbf{4}$ was deduced to be $4 Z, 7 Z$ from the ${ }^{13} \mathrm{C}-\mathrm{NMR}$ chemical shifts of allylic methylenes, with sterically induced upfield shifts being observed at C-3 $(\delta$ 24.5), C-6 ( $\delta$ 26.3) and C-9 $(\delta$ 21.4) of 4, and NOESY cross-peaks observed between H-3/H-6 and H-6/H9. 4 had been reported as an antibacterial and antifungal compound isolated from the hepatopancreas of the ascidian Halocynthia roretzi. ${ }^{12)}$

The molecular formula of 5 was established as $\mathrm{C}_{12} \mathrm{H}_{23} \mathrm{O}_{4} \mathrm{~S}$ on the basis of HR-FAB-MS. The presence of a sulfate group was suggested by a fragment ion peak at $m / z 97\left(\mathrm{HSO}_{4}^{-}\right)$in the negative ion FAB-MS of 5 . The ${ }^{1} \mathrm{H}-\mathrm{NMR}$ spectrum of 5 exhibited two olefinic protons at $5.53(1 \mathrm{H}, \mathrm{dt}, J=\underline{11.0}$, $7.1 \mathrm{~Hz} ; \mathrm{H}-4)$ and $5.44(1 \mathrm{H}, \mathrm{dt}, J=\underline{11.0}, 7.1 \mathrm{~Hz} ; \mathrm{H}-3)$, two methylene protons bearing a sulfate group at $\delta 4.00(2 \mathrm{H}, \mathrm{t}$, $J=7.2 \mathrm{~Hz} ; \mathrm{H}-1)$, a methyl group at $\delta 0.94(3 \mathrm{H}, \mathrm{t}, J=6.6 \mathrm{~Hz}$; $\mathrm{H}-10)$, and sixteen methylene protons at $\delta 2.46-1.25$. The ${ }^{1} \mathrm{H}-{ }^{1} \mathrm{H}$ COSY spectrum of the compound was consistent with the structure, 3-dodecenyl sulfate. The geometry of the double bonds in 5 was deduced to be $3 Z$ from the underlined coupling constants of the olefinic protons.
The molecular formula of $\mathbf{6}$ was established as $\mathrm{C}_{10} \mathrm{H}_{20} \mathrm{O}_{3} \mathrm{NS}$ on the basis of HR-FAB-MS. The ${ }^{1} \mathrm{H}-\mathrm{NMR}$ spectrum of 6 exhibited two olefinic protons at $\delta 5.50(1 \mathrm{H}$, $\mathrm{dt}, J=\underline{11.0}, 7.0 \mathrm{~Hz} ; \mathrm{H}-4)$ and $5.42(1 \mathrm{H}, \mathrm{dt}, J=\underline{11.0}, 7.0 \mathrm{~Hz}$; $\mathrm{H}-3)$, two methylene protons bearing a sulfamate group at $\delta$ $3.03(2 \mathrm{H}, \mathrm{t}, J=7.0 \mathrm{~Hz} ; \mathrm{H}-1)$, a methyl group at $\delta 0.94(3 \mathrm{H}, \mathrm{t}$, $J=7.0 \mathrm{~Hz} ; \mathrm{H}-10)$, and twelve methylene protons at $\delta 2.34$ 1.33. The ${ }^{1} \mathrm{H}-{ }^{1} \mathrm{H}$ COSY spectrum of the compound was consistent with the structure of 3-decenyl sulfamate. The geometry of the double bonds in $\mathbf{6}$ was deduced to be $3 Z$ from the ${ }^{13} \mathrm{C}-\mathrm{NMR}$ chemical shifts of allylic methylenes, with sterically induced upfield shifts being observed at C-2 ( $\delta$ 28.7) and C-5 $(\delta 28.3)$ of 6 , NOESY cross-peaks observed between $\mathrm{H}-2 / \mathrm{H}-5$ and $\mathrm{H}-3 / \mathrm{H}-4$ and the underlined coupling constants of the olefinic protons.

The molecular formula of 7 was established as $\mathrm{C}_{12} \mathrm{H}_{22} \mathrm{O}_{3} \mathrm{NS}$ on the basis of HR-FAB-MS. The ${ }^{1} \mathrm{H}-\mathrm{NMR}$ spectrum of 7 exhibited two olefinic protons at $\delta 5.47-5.37$ $(4 \mathrm{H}, \mathrm{m} ; \mathrm{H}-3,4,6,7)$, two methylene protons bearing a sulfamate group at $\delta 3.04(2 \mathrm{H}, \mathrm{t}, J=7.0 \mathrm{~Hz} ; \mathrm{H}-1)$, a methyl group at $\delta 0.95(3 \mathrm{H}, \mathrm{t}, J=7.0 \mathrm{~Hz} ; \mathrm{H}-12)$, and 12 methylene protons at $\delta 2.88-1.33$. The ${ }^{1} \mathrm{H}-{ }^{1} \mathrm{H}$ COSY spectrum of the compound was consistent with the structure of 3,6-dodecadienyl sulfamate.

The molecular formula of $\mathbf{8}$ was established as $\mathrm{C}_{10} \mathrm{H}_{22} \mathrm{O}_{3} \mathrm{NS}$ on the basis of HR-TOF-MS. The ${ }^{1} \mathrm{H}-\mathrm{NMR}$ spectrum of $\mathbf{8}$ exhibited two methylene protons bearing a sulfamate group at $\delta 3.01(2 \mathrm{H}, \mathrm{t}, J=7.0 \mathrm{~Hz} ; \mathrm{H}-1)$, a methyl group at $\delta 0.94(3 \mathrm{H}, \mathrm{t}, J=7.0 \mathrm{~Hz} ; \mathrm{H}-9)$, and twelve methylene protons at $\delta 1.58-1.34$. The ${ }^{1} \mathrm{H}-{ }^{1} \mathrm{H}$ COSY spectrum of the compound was consistent with the structure, decyl sulfamate.

The molecular formula of 9 was established as $\mathrm{C}_{9} \mathrm{H}_{20} \mathrm{O}_{3} \mathrm{NS}$ on the basis of HR-TOF-MS. The ${ }^{1} \mathrm{H}-\mathrm{NMR}$ spectrum of 9 exhibited two methylene protons bearing a sulfamate group at $\delta 3.01(2 \mathrm{H}, \mathrm{t}, J=7.0 \mathrm{~Hz} ; \mathrm{H}-1)$, a methyl group at $\delta 0.94$ $(3 \mathrm{H}, \mathrm{t}, J=7.0 \mathrm{~Hz} ; \mathrm{H}-9)$, and fourteen methylene protons at $\delta$ 1.58-1.34. The ${ }^{1} \mathrm{H}-{ }^{1} \mathrm{H}$ COSY spectrum of the compound was consistent with the structure of nonyl sulfamate.

The molecular formula of $\mathbf{1 0}$ was established as $\mathrm{C}_{8} \mathrm{H}_{18} \mathrm{O}_{3} \mathrm{NS}$ on the basis of HR-TOF-MS. The ${ }^{1} \mathrm{H}-\mathrm{NMR}$ spectrum of $\mathbf{1 0}$ exhibited two methylene protons bearing a sulfamate group at $\delta 3.01(2 \mathrm{H}, \mathrm{t}, J=7.0 \mathrm{~Hz} ; \mathrm{H}-1)$, a methyl group at $\delta 0.94(3 \mathrm{H}, \mathrm{t}, J=7.0 \mathrm{~Hz} ; \mathrm{H}-8)$, and sixteen methylene protons at $\delta 1.58-1.36$. The ${ }^{1} \mathrm{H}-{ }^{1} \mathrm{H}$ COSY spectrum of the compound was consistent with the structure of octyl sulfamate. To the best of our knowledge, compound $\mathbf{1 0}$ was first isolated as a natural product which had been reported as a synthetic material. ${ }^{13)}$

The molecular formula of $\mathbf{1 1}$ was established as $\mathrm{C}_{11} \mathrm{H}_{24} \mathrm{O}_{3} \mathrm{NS}$ on the basis of HR-FAB-MS. The ${ }^{1} \mathrm{H}-\mathrm{NMR}$ spectrum of $\mathbf{1 1}$ exhibited two methylene protons bearing a sulfamate group at $\delta 2.99(2 \mathrm{H}, \mathrm{t}, J=7.0 \mathrm{~Hz} ; \mathrm{H}-1)$, two doublet methyls at $\delta 0.92(6 \mathrm{H}, \mathrm{d}, J=7.0 \mathrm{~Hz} ; \mathrm{H}-10$, Me-9) and fifteen methine/methylene protons at $\delta 1.57-1.19$. Interpretation of the ${ }^{1} \mathrm{H}-{ }^{1} \mathrm{H}$ COSY spectrum of $\mathbf{1 1}$ led to a gross structure as 9-methyldecyl sulfamate.

The molecular formula of $\mathbf{1 2}$ was established as $\mathrm{C}_{10} \mathrm{H}_{22} \mathrm{O}_{3} \mathrm{NS}$ on the basis of HR-FAB-MS. The ${ }^{1} \mathrm{H}-\mathrm{NMR}$ spectrum of 12 exhibited two methylene protons bearing a sulfamate group at $\delta 3.01(2 \mathrm{H}, \mathrm{t}, J=7.0 \mathrm{~Hz} ; \mathrm{H}-1)$, two dou- 
blet methyls at $\delta 0.92(6 \mathrm{H}, \mathrm{d}, J=7.0 \mathrm{~Hz} ; \mathrm{H}-9, \mathrm{Me}-8)$ and thirteen methine/methylene protons at $\delta 1.58-1.23$. Interpretation of the ${ }^{1} \mathrm{H}-{ }^{1} \mathrm{H}$ COSY spectrum of $\mathbf{1 2}$ led to a gross structure as 8-methylnonyl sulfamate.

The molecular formula of $\mathbf{1 3}$ was established as $\mathrm{C}_{9} \mathrm{H}_{20} \mathrm{O}_{3} \mathrm{NS}$ on the basis of HR-FAB-MS. The ${ }^{1} \mathrm{H}-\mathrm{NMR}$ spectrum of 13 exhibited two methylene protons bearing a sulfamate group at $\delta 3.01(2 \mathrm{H}, \mathrm{t}, J=7.0 \mathrm{~Hz} ; \mathrm{H}-1)$, two doublet methyls at $\delta 0.92(6 \mathrm{H}, \mathrm{d}, J=7.0 \mathrm{~Hz} ; \mathrm{H}-8, \mathrm{Me}-7)$ and eleven methine/methylene protons at $\delta 1.63-1.24$. Interpretation of the ${ }^{1} \mathrm{H}-{ }^{1} \mathrm{H}$ COSY spectrum of $\mathbf{1 3}$ led to a gross structure as 7-methyloctyl sulfamate.

\section{Experimental}

High-resolution MS were recorded on a JEOL JMS-SX102A spectrometer and Waters LCT Premier. ${ }^{1} \mathrm{H}$ - and ${ }^{13} \mathrm{C}-\mathrm{NMR}$ spectra were obtained on a Bruker Avance-400 $\left({ }^{1} \mathrm{H}\right.$ and ${ }^{13} \mathrm{C}$ at 400 and $100 \mathrm{MHz}$, respectively). Assignments of the proton and carbon signals were established by COSY, HSQC and HMBC spectra. Optical rotations were determined on a JASCO DIP-370 polarimeter. The structures of the compounds were established by COSY, HSQC, HMBC, and NOESY spectra. The countercation of natural sulfates was not identified and expressed as $\mathrm{M}^{+}$

Bioassay Each $200 \mathrm{ml}$ of $\mathrm{C}$ medium of $S$. gutwinskii $\left(5.0 \times 10^{2}\right.$ cells $\left./ \mathrm{ml}\right)$ is delivered into the central $30-50$ wells of 96 -well polystyrene tissue culture plate (CELLSTAR, Greiner Bio-one Co., Ltd.) containing the test samples $(1000-0.01 \mathrm{ng} / \mathrm{ml})$, and the outer wells are filled with distilled water to avoid dehydration of the system. The plate is covered with a plastic lid, and incubated at $20^{\circ} \mathrm{C}$ (12 light/ 12 dark) for $10 \mathrm{~d}$. A drop of the medium is placed on a Thoma's hemacytometer, and the numbers of 1-, 2-, 4-, and 8cell types were counted under a microscope $(\times 200)$.

Extraction and Isolation Frozen Daphnia $(10 \mathrm{~kg}$; Aso Tropical Fish Co., Ltd., Osaka) was soaked with methanol $(201 \times 3)$, and the methanol solution was evaporated, the residue being treated with water (91). The mixture was successively extracted with hexane (91), dichloromethane (91), and butanol (91), and the most active butanol extract (18g) was chromatographed on a Cosmosil $75 \mathrm{C}_{18}-\mathrm{OPN}(25 \mathrm{~g})$, eluting with $\mathrm{MeOH}-\mathrm{H}_{2} \mathrm{O}$ in a gradient manner $(1: 1 \rightarrow 10: 0)$. The active fractions were further purified by HPLC (CAPCELLPAK $\mathrm{C}_{18}$ column, $5 \mu \mathrm{m}, 10 \times 250 \mathrm{~mm}, \mathrm{MeCN}-\mathrm{H}_{2} \mathrm{O}(40: 60)$ containing $250 \mathrm{~mm} \mathrm{NaClO}$ as mobile phase with the flow rate $1.0 \mathrm{ml} / \mathrm{min}$ using an RI detector) to afford $\mathbf{1}(8.0 \mathrm{mg}), \mathbf{2}(0.5 \mathrm{mg}), \mathbf{3}(0.3 \mathrm{mg}), \mathbf{4}(3.8 \mathrm{mg}), \mathbf{5}$ $(0.5 \mathrm{mg}), \mathbf{6}(8.0 \mathrm{mg}), 7(0.4 \mathrm{mg}), \mathbf{8}(0.8 \mathrm{mg}) \mathbf{9}(0.6 \mathrm{mg}), \mathbf{1 0}(1.5 \mathrm{mg}), \mathbf{1 1}$ $(0.1 \mathrm{mg}), \mathbf{1 2}(0.2 \mathrm{mg})$, and $\mathbf{1 3}(1.5 \mathrm{mg})$.

7-Methyloctyl Sulfate (1) White waxy solid. ${ }^{1} \mathrm{H}-\mathrm{NMR}\left(\mathrm{CD}_{3} \mathrm{OD}\right) \delta$ : $4.03(2 \mathrm{H}, \mathrm{t}, J=6.6 \mathrm{~Hz} ; \mathrm{H}-1), 1.68(2 \mathrm{H}$, quint, $J=6.6 \mathrm{~Hz} ; \mathrm{H}-2), 1.56(1 \mathrm{H}$, nonet, $J=6.8 \mathrm{~Hz} ; \mathrm{H}-7), 1.48-1.30(6 \mathrm{H}, \mathrm{m} ; \mathrm{H}-3,4,5), 1.23(2 \mathrm{H}, \mathrm{m} ; \mathrm{H}-6)$, $0.92(6 \mathrm{H}, \mathrm{d}, J=6.6 \mathrm{~Hz} ; \mathrm{H}-8, \mathrm{Me}-7) .{ }^{13} \mathrm{C}-\mathrm{NMR}\left(\mathrm{CD}_{3} \mathrm{OD}\right) \delta: 69.2(\mathrm{C}-1), 40.1$ (C-6), $30.6(\mathrm{C}-2)^{\mathrm{a}}, 30.5(\mathrm{C}-4)^{\mathrm{a}}, 29.1$ (C-7), 28.4 (C-5), 26.9 (C-3), 23.1 (C-8, Me-7). HR-FAB-MS (-): $m / z 223.0978$ (Calcd for $\mathrm{C}_{9} \mathrm{H}_{19} \mathrm{O}_{4} \mathrm{~S}: 223.1004$ ). ${ }^{a}$ These resonances may be interchangeable

Synthesis of Sodium 7-Methyloctyl Sulfate (1) $1.6 \mathrm{~m}$ Solution of $n$ BuLi in hexane $(0.24 \mathrm{ml}, 0.7 \mathrm{mmol})$ was added dropwise to a suspension of isopropyltriphenylphosphonium iodide $(370 \mathrm{mg}, 0.9 \mathrm{mmol})$ in THF $(4 \mathrm{ml})$. The mixture was stirred at $-30{ }^{\circ} \mathrm{C}$ for $20 \mathrm{~min}$, cooled at $-78^{\circ} \mathrm{C}$ and a solution of adipic semialdehyde methyl ester $14(95 \mathrm{mg}, 0.7 \mathrm{mmol}$; commercially available) in THF $(2 \mathrm{ml})$ was added. The mixture was stirred at the same temperature for $2 \mathrm{~h}$, poured into water, extracted with diethyl ether. The organic layer was dried over $\mathrm{Na}_{2} \mathrm{SO}_{4}$. After concentration, the crude product was purified by flash chromatography to give the methyl ester $15(83 \mathrm{mg}$, 74\%). 15; ${ }^{1} \mathrm{H}-\mathrm{NMR}\left(400 \mathrm{MHz}, \mathrm{CDCl}_{3}\right) \delta: 5.09(2 \mathrm{H}, \mathrm{m}), 3.66(3 \mathrm{H}, \mathrm{s}), 2.30$ $(2 \mathrm{H}, \mathrm{t}, 7.8), 1.98(2 \mathrm{H}, \mathrm{q}, 7.6), 1.67(3 \mathrm{H}, \mathrm{s}), 1.62(2 \mathrm{H}, \mathrm{m}), 1.59(3 \mathrm{H}, \mathrm{s}), 1.34$ $(2 \mathrm{H}, \mathrm{m}) .{ }^{13} \mathrm{C}-\mathrm{NMR}\left(100 \mathrm{MHz}, \mathrm{CDCl}_{3}\right) \delta: 174.1,131.6,124.1,51.5,34.1$, $29.4,27.7,25.8,24.7,17.7$. To $75 \mathrm{mg}(0.4 \mathrm{mmol})$ of methyl 7-methyl-6-octenate 15 in $\mathrm{MeOH}(5 \mathrm{ml})$ was added $\mathrm{Pd}-\mathrm{C}$ catalyst $(24 \mathrm{mg}, 10 \% \mathrm{w} / \mathrm{w})$. The reaction mixture was stirred at room temperature for $2 \mathrm{~h}$ under hydrogen atmosphere. The mixture was filtered and the ester $(60 \mathrm{mg}, 78 \%)$ was obtained after concentration. To a solution of $60 \mathrm{mg}(0.4 \mathrm{mmol})$ of the ester in THF $(3 \mathrm{ml})$ was added $39 \mathrm{mg}(1.0 \mathrm{mmol})$ of $\mathrm{LiAlH}_{4}$. After $1 \mathrm{~h}$, the reaction was quenched by adding $50 \mu \mathrm{l}$ of $\mathrm{H}_{2} \mathrm{O}, 15 \% \mathrm{NaOH}$, and then $200 \mu \mathrm{l}$ of $\mathrm{H}_{2} \mathrm{O}$. The mixture was diluted with EtOAc and filtered through Celite. The filtrate was concentrated under reduced pressure to furnish $24 \mathrm{mg}(0.2 \mathrm{mmol}, 48 \%)$ of 7-Methyloctan-1-ol 16. 16; ${ }^{1} \mathrm{H}-\mathrm{NMR}\left(400 \mathrm{MHz}, \mathrm{CDCl}_{3}\right) \delta: 3.65(2 \mathrm{H}, \mathrm{t}$, $J=6.6 \mathrm{~Hz}, \mathrm{H}-1), 1.66-1.46(3 \mathrm{H}, \mathrm{m}), 1.28(4 \mathrm{H}, \mathrm{m}), 1.16(2 \mathrm{H}, \mathrm{m}), 0.85(6 \mathrm{H}$ d, $J=6.6 \mathrm{~Hz}) .{ }^{13} \mathrm{C}-\mathrm{NMR}\left(100 \mathrm{MHz}, \mathrm{CDCl}_{3}\right) \delta: 61.3(\mathrm{C}-1), 39.0(\mathrm{C}-6), 32.9$ (C-2), 29.7 (C-4), 28.0 (C-7), 27.4 (C-5), 25.8 (C-3), 22.7 (C-8 and Me-7) The alcohol 16 (24 mg, $0.2 \mathrm{mmol}$ ) was converted to the sulfate by treatment with pyridine- $\mathrm{SO}_{3}$ complex $(104 \mathrm{mg}, 0.7 \mathrm{mmol})$ in tetrahydrofuran $(3 \mathrm{ml})$ at room temperature for $24 \mathrm{~h}$. The resulting mixture was neutralized with $1 \mathrm{M}$ sodium hydroxide solution and the aqueous solution was extracted with hexane to remove the residual alcohol. The aqueous layer was passed through an ODS column. Mineral salt was removed by washing the column with distilled water and elution with methanol gave 1 (49 mg quant.). The ${ }^{1} \mathrm{H}$ - and ${ }^{13} \mathrm{C}$-NMR spectra of this product were identical with those of natural 1.

3E-Decenyl Sulfate (2) White waxy solid. ${ }^{1} \mathrm{H}-\mathrm{NMR}\left(\mathrm{CD}_{3} \mathrm{OD}\right) \boldsymbol{\delta}: 5.59$ $(1 \mathrm{H}, \mathrm{dtd}, J=15.2,6.6,1.2 \mathrm{~Hz} ; \mathrm{H}-4), 5.47(1 \mathrm{H}, \mathrm{dtd}, J=15.2,6.6,1.2 \mathrm{~Hz} ; \mathrm{H}-$ 3), $4.01(2 \mathrm{H}, \mathrm{t}, J=7.1 \mathrm{~Hz} ; \mathrm{H}-1), 2.39(2 \mathrm{H}, \mathrm{qd}, J=6.6,1.2 \mathrm{~Hz} ; \mathrm{H}-2), 2.04$ $(2 \mathrm{H}, \mathrm{q}, J=6.6 \mathrm{~Hz} ; \mathrm{H}-5), 1.45-1.30(8 \mathrm{H}$, envelop, $\mathrm{H}-6,7,8,9), 0.94(3 \mathrm{H}, \mathrm{t}$ $J=7.1 \mathrm{~Hz} ; \mathrm{H}-10$ ). (Underlined coupling constants support the $E$-configuration of the olefin.) ${ }^{13} \mathrm{C}-\mathrm{NMR}\left(\mathrm{CD}_{3} \mathrm{OD}\right) \delta: 134.3(\mathrm{C}-4), 126.6(\mathrm{C}-3), 68.9(\mathrm{C}-$ 1), 33.7 (C-2 and 5), 32.9 (C-8), 30.5 (C-6), 29.9 (C-7), 23.7 (C-9), 14.4 (C10). HR-FAB-MS (-): $m / z 235.0992$ (Calcd for $\mathrm{C}_{10} \mathrm{H}_{19} \mathrm{O}_{4} \mathrm{~S}: 235.1004$ ).

9-Methyl-3Z-decenyl Sulfate (3) White waxy solid. ${ }^{1} \mathrm{H}-\mathrm{NMR}\left(\mathrm{CD}_{3} \mathrm{OD}\right)$ $\delta: 5.52(1 \mathrm{H}, \mathrm{dt}, J=\underline{11.5}, 7.1 \mathrm{~Hz} ; \mathrm{H}-4), 5.44(1 \mathrm{H}, \mathrm{dt}, J=\underline{11.5}, 7.1 \mathrm{~Hz} ; \mathrm{H}-3)$ $4.00(2 \mathrm{H}, \mathrm{t}, J=7.2 \mathrm{~Hz} ; \mathrm{H}-1), 2.46(2 \mathrm{H}, \mathrm{q}, J=6.8 \mathrm{~Hz} ; \mathrm{H}-2), 2.12(2 \mathrm{H}, \mathrm{m} ; \mathrm{H}-$ 5), $1.57(1 \mathrm{H}$, nonet, $J=6.6 \mathrm{~Hz} ; \mathrm{H}-9), 1.45-1.30(4 \mathrm{H}, \mathrm{m}, \mathrm{H}-6,7), 1.25(2 \mathrm{H}$ $\mathrm{m} ; \mathrm{H}-8), 0.92(6 \mathrm{H}, \mathrm{d}, J=6.6 \mathrm{~Hz} ; \mathrm{H}-10, \mathrm{Me}-9)$. (Underlined coupling constants support the Z-configuration of the olefin.) HR-FAB-MS (-): $\mathrm{m} / \mathrm{z}$ 249.1173 (Calcd for $\mathrm{C}_{11} \mathrm{H}_{21} \mathrm{O}_{4} \mathrm{~S}: 249.1161$ ).

4Z,7Z-Decadienyl Sulfate (4) ${ }^{12)}$ White waxy solid. ${ }^{1} \mathrm{H}-\mathrm{NMR}\left(\mathrm{CD}_{3} \mathrm{OD}\right)$ $\delta: 5.45-5.30(4 \mathrm{H}, \mathrm{m} ; \mathrm{H}-4,5,7,8), 4.04(2 \mathrm{H}, \mathrm{t}, J=7.0 \mathrm{~Hz} ; \mathrm{H}-1), 2.85(2 \mathrm{H}$ $\mathrm{m} ; \mathrm{H}-6), 2.23(2 \mathrm{H}, \mathrm{m} ; \mathrm{H}-3), 2.13(2 \mathrm{H}, \mathrm{m} ; \mathrm{H}-9), 1.76(2 \mathrm{H}, \mathrm{m} ; \mathrm{H}-2), 1.01(3 \mathrm{H}$ $\mathrm{t}, J=7.0 \mathrm{~Hz} ; \mathrm{H}-10)$. NOESY cross-peaks between $\mathrm{H}-3 / \mathrm{H}-6$ and $\mathrm{H}-6 / \mathrm{H}-9$ are consistent with the $Z$-configurations. ${ }^{13} \mathrm{C}-\mathrm{NMR}\left(\mathrm{CD}_{3} \mathrm{OD}\right) \delta: 132.7(\mathrm{C}-4)^{\mathrm{a}}$, $130.1(\mathrm{C}-8)^{\mathrm{a}}, 129.8(\mathrm{C}-7)^{\mathrm{a}}, 128.4(\mathrm{C}-5)^{\mathrm{a}}, 68.5$ (C-1), 30.5 (C-2), 26.3 (C-6), 24.5 (C-3), 21.4 (C-9), 14.7 (C-10). (Underlined chemical shifts of allylic carbons support the $Z$-configurations of the olefins.) HR-FAB-MS (-): $\mathrm{m} / \mathrm{z}$ 233.0859 (Calcd for $\mathrm{C}_{10} \mathrm{H}_{17} \mathrm{O}_{4} \mathrm{~S}: 233.0848$ ). ${ }^{\text {a }}$ These resonances may be interchangeable.

3Z-Dodecenyl Sulfate (5) White waxy solid. ${ }^{1} \mathrm{H}-\mathrm{NMR}\left(\mathrm{CD}_{3} \mathrm{OD}\right) \delta$ $5.53(1 \mathrm{H}, \mathrm{dt}, J=\underline{11.0}, 7.1 \mathrm{~Hz} ; \mathrm{H}-4), 5.44(1 \mathrm{H}, \mathrm{dt}, J=\underline{11.0}, 7.1 \mathrm{~Hz} ; \mathrm{H}-3), 4.00$ $(2 \mathrm{H}, \mathrm{t}, J=7.2 \mathrm{~Hz} ; \mathrm{H}-1), 2.46(2 \mathrm{H}, \mathrm{q}, J=6.8 \mathrm{~Hz} ; \mathrm{H}-2), 2.10(2 \mathrm{H}, \mathrm{m} ; \mathrm{H}-5)$ $1.50-1.25(12 \mathrm{H}$, envelop, H-6, 7, 8, 9, 10, 11), $0.94(3 \mathrm{H}, \mathrm{t}, J=6.6 \mathrm{~Hz} ; \mathrm{H}-$ 12). (Underlined coupling constants support the $Z$-configuration of the olefin.) ${ }^{13} \mathrm{C}$-NMR $\left(\mathrm{CD}_{3} \mathrm{OD}\right) \delta: 133.5(\mathrm{C}-4), 125.7$ (C-3), $68.6(\mathrm{C}-1), 33.1$ $(\mathrm{C}-10), 30.7(\mathrm{C}-6)^{\mathrm{a}}, 30.6(\mathrm{C}-7)^{\mathrm{a}}, 30.4(\mathrm{C}-8)^{\mathrm{a}}, 30.4(\mathrm{C}-9)^{\mathrm{a}}, 28.6(\mathrm{C}-3), 28.3$ (C-2), 23.7 (C-11), 14.4 (C-12). HR-FAB-MS (-): $m / z 263.1335$ (Calcd for $\left.\mathrm{C}_{12} \mathrm{H}_{23} \mathrm{O}_{4} \mathrm{~S}: 263.1317\right) .{ }^{\text {a }}$ These resonances may be interchangeable.

3Z-Decenyl Sulfamate (6) White waxy solid. ${ }^{1} \mathrm{H}-\mathrm{NMR}\left(\mathrm{CD}_{3} \mathrm{OD}\right) \delta$ : $5.50(1 \mathrm{H}, \mathrm{dt}, J=11.0,7.0 \mathrm{~Hz} ; \mathrm{H}-4), 5.42(1 \mathrm{H}, \mathrm{dt}, J=11.0,7.0 \mathrm{~Hz} ; \mathrm{H}-3), 3.03$ $(2 \mathrm{H}, \mathrm{t}, J=7.0 \mathrm{~Hz} ; \mathrm{H}-1), 2.34(2 \mathrm{H}, \mathrm{q}, J=7.0 \mathrm{~Hz} ; \mathrm{H}-2), 2.12(2 \mathrm{H}, \mathrm{q}, J=7.0 \mathrm{~Hz}$ $\mathrm{H}-5), 1.37$ (2H, overlapped, H-6), 1.33 (6H, envelop, $\mathrm{H}-7,8,9), 0.94(3 \mathrm{H}, \mathrm{t}$ $J=7.0 \mathrm{~Hz} ; \mathrm{H}-10)$. NOESY cross-peaks were observed between $\mathrm{H}-2 / \mathrm{H}-5$ and $\mathrm{H}-3 / \mathrm{H}-4$. (Underlined coupling constants and NOEs support the Z-configuration of the olefin.) ${ }^{13} \mathrm{C}-\mathrm{NMR}\left(\mathrm{CD}_{3} \mathrm{OD}\right) \delta: 132.9$ (C-4), 127.5 (C-3), 44.8 (C-1), 32.9 (C-8), 30.7 (C-6), 30.0 (C-7), 28.7 (C-2), 28.3 (C-5), 23.7 (C-9), 14.4 (C-10). (Underlined chemical shifts of allylic carbons support the $Z$ configurations of the olefins.) HR-FAB-MS (-): $m / z 234.1175$ (Calcd for $\left.\mathrm{C}_{10} \mathrm{H}_{20} \mathrm{O}_{3} \mathrm{NS}: 234.1164\right)$.

3,6-Dodecadienyl Sulfamate (7) White waxy solid. ${ }^{1} \mathrm{H}-\mathrm{NMR}\left(\mathrm{CD}_{3} \mathrm{OD}\right)$ $\delta: 5.47-5.37(4 \mathrm{H}, \mathrm{m} ; \mathrm{H}-3,4,6,7), 3.04(2 \mathrm{H}, \mathrm{t}, J=7.0 \mathrm{~Hz} ; \mathrm{H}-1), 2.88(2 \mathrm{H}$ t, $J=7.0 \mathrm{~Hz} ; \mathrm{H}-5), 2.37(2 \mathrm{H}, \mathrm{q}, J=7.0 \mathrm{~Hz} ; \mathrm{H}-2), 2.12(2 \mathrm{H}, \mathrm{q}, J=7.0 \mathrm{~Hz} ; \mathrm{H}-$ 8), 1.33 (6H, envelop; H-9, 10, 11), $0.95(3 \mathrm{H}, \mathrm{t}, J=7.0 \mathrm{~Hz}$; H-12). HR-FABMS (-): $m / z 260.1328$ (Calcd for $\mathrm{C}_{12} \mathrm{H}_{22} \mathrm{O}_{3} \mathrm{NS}: 260.1320$ ).

Decyl Sulfamate (8) White waxy solid. ${ }^{1} \mathrm{H}-\mathrm{NMR}\left(\mathrm{CD}_{3} \mathrm{OD}\right) \delta: 3.01$ $(2 \mathrm{H}, \mathrm{t}, J=7.0 \mathrm{~Hz} ; \mathrm{H}-1), 1.58(2 \mathrm{H}, \mathrm{m} ; \mathrm{H}-2), 1.34(12 \mathrm{H}$, envelop; $\mathrm{H}-3,4,5,6$, $7,8,9), 0.94(3 \mathrm{H}, \mathrm{t}, J=7.0 \mathrm{~Hz} ; \mathrm{H}-10) .{ }^{13} \mathrm{C}-\mathrm{NMR}\left(\mathrm{CD}_{3} \mathrm{OD}\right) \delta: 45.0(\mathrm{C}-1)$ $33.1(\mathrm{C}-8) 30.9(\mathrm{C}-2)^{\mathrm{a}}, 30.7(\mathrm{C}-4)^{\mathrm{a}}, 30.7(\mathrm{C}-5)^{\mathrm{a}}, 30.6(\mathrm{C}-6)^{\mathrm{a}}, 30.5(\mathrm{C}-7)^{\mathrm{a}}$, 28.2 (C-3), 23.7 (C-9), 14.5 (C-10). ${ }^{\text {a }}$ These resonances may be interchangeable. HR-TOF-MS (-): $m / z 236.1321$ (Calcd for $\mathrm{C}_{10} \mathrm{H}_{22} \mathrm{O}_{3} \mathrm{NS}: 236.1320$ ).

Decyl amine $(52 \mathrm{mg}, 0.3 \mathrm{mmol})$ was converted to the sulfate by treatment with pyridine- $\mathrm{SO}_{3}$ complex $(210 \mathrm{mg}, 1.3 \mathrm{mmol})$ in tetrahydrofuran $(3 \mathrm{ml})$ at room temperature for $24 \mathrm{~h}$. The resulting mixture was neutralized with $1 \mathrm{M}$ sodium hydroxide solution and the aqueous solution was extracted with hexane to remove the residual alcohol. The aqueous layer was passed through an ODS column. Mineral salt was removed by washing the column with distilled water and elution with methanol gave $8(56 \mathrm{mg}, 66 \%)$. The ${ }^{1} \mathrm{H}-$ 
and ${ }^{13} \mathrm{C}$-NMR spectra of this product were identical with those of natural $\mathbf{8}$.

Nonyl Sulfamate (9) White waxy solid. ${ }^{1} \mathrm{H}-\mathrm{NMR}\left(\mathrm{CD}_{3} \mathrm{OD}\right) \delta: 3.01$ $(2 \mathrm{H}, \mathrm{t}, J=7.0 \mathrm{~Hz} ; \mathrm{H}-1), 1.58$ (2H, m; H-2), 1.34 (12H, envelop; H-3, 4, 5, 6, 7, 8), $0.94\left(3 \mathrm{H}, \mathrm{t}, J=7.0 \mathrm{~Hz}\right.$; H-9). ${ }^{13} \mathrm{C}-\mathrm{NMR}\left(\mathrm{CD}_{3} \mathrm{OD}\right) \delta: 45.0(\mathrm{C}-1), 33.1$ (C-7) $30.9(\mathrm{C}-2)^{\mathrm{a}}, 30.7(\mathrm{C}-4)^{\mathrm{a}}, 30.6(\mathrm{C}-5)^{\mathrm{a}}, 30.4(\mathrm{C}-6)^{\mathrm{a}}, 28.2$ (C-3), 23.7 (C8), 14.5 (C-9). ${ }^{a}$ These resonances may be interchangeable. HR-TOF-MS $(-): m / z 222.1125$ (Calcd for $\left.\mathrm{C}_{9} \mathrm{H}_{20} \mathrm{O}_{3} \mathrm{NS}: 222.1164\right)$.

Nonyl amine $(57 \mathrm{mg}, 0.4 \mathrm{mmol}$ ) was converted to the sulfate by treatment with pyridine $-\mathrm{SO}_{3}$ complex $(265 \mathrm{mg}, 1.6 \mathrm{mmol})$ in tetrahydrofuran $(3 \mathrm{ml})$ at room temperature for $24 \mathrm{~h}$. The resulting mixture was neutralized with $1 \mathrm{~m}$ sodium hydroxide solution and the aqueous solution was extracted with hexane to remove the residual alcohol. The aqueous layer was passed through an ODS column. Mineral salt was removed by washing the column with distilled water and elution with methanol gave $9(36 \mathrm{mg}, 36 \%)$. The ${ }^{1} \mathrm{H}-$ and ${ }^{13} \mathrm{C}$-NMR spectra of this product were identical with those of natural 9 .

Octyl Sulfamate (10) White waxy solid. ${ }^{1} \mathrm{H}-\mathrm{NMR}\left(\mathrm{CD}_{3} \mathrm{OD}\right) \delta: 3.01$ $(2 \mathrm{H}, \mathrm{t}, J=7.0 \mathrm{~Hz} ; \mathrm{H}-1), 1.58(2 \mathrm{H}, \mathrm{m} ; \mathrm{H}-2), 1.36(10 \mathrm{H}$, envelop; H-3, 4, 5, 6, 7), $0.94(3 \mathrm{H}, \mathrm{t}, J=7.0 \mathrm{~Hz} ; \mathrm{H}-8) .{ }^{13} \mathrm{C}-\mathrm{NMR}\left(\mathrm{CD}_{3} \mathrm{OD}\right) \delta: 45.0(\mathrm{C}-1), 33.0(\mathrm{C}-$ 6) 30.9 (C-2), $30.5(\mathrm{C}-4)^{\mathrm{a}}, 30.4(\mathrm{C}-5)^{\mathrm{a}}, 28.3$ (C-3), 23.7 (C-7), $14.5(\mathrm{C}-8)$. ${ }^{\text {a }}$ These resonances may be interchangeable. HR-TOF-MS (-): $m / z 208.1050$ (Calcd for $\mathrm{C}_{8} \mathrm{H}_{18} \mathrm{O}_{3} \mathrm{NS}$ : 208.1007).

Octyl amine $(51 \mathrm{mg}, 0.4 \mathrm{mmol})$ was converted to the sulfate by treatment with pyridine- $\mathrm{SO}_{3}$ complex $(250 \mathrm{mg}, 1.6 \mathrm{mmol})$ in tetrahydrofuran $(3 \mathrm{ml})$ at room temperature for $24 \mathrm{~h}$. The resulting mixture was neutralized with $1 \mathrm{~m}$ sodium hydroxide solution and the aqueous solution was extracted with hexane to remove the residual alcohol. The aqueous layer was passed through an ODS column. Mineral salt was removed by washing the column with distilled water and elution with methanol gave $10(12 \mathrm{mg}, 15 \%)$. The ${ }^{1} \mathrm{H}$ - and ${ }^{13} \mathrm{C}$-NMR spectra of this product were identical with those of natural 10

9-Methyldecyl Sulfamate (11) White waxy solid. ${ }^{1} \mathrm{H}-\mathrm{NMR}\left(\mathrm{CD}_{3} \mathrm{OD}\right)$ $\delta: 2.99(2 \mathrm{H}, \mathrm{t}, J=7.0 \mathrm{~Hz} ; \mathrm{H}-1), 1.57(3 \mathrm{H}, \mathrm{m} ; \mathrm{H}-2,9), 1.33$ (10H, envelop; H$3,4,5,6,7), 1.19(2 \mathrm{H}, \mathrm{m} ; \mathrm{H}-8), 0.92(6 \mathrm{H}, \mathrm{d}, J=7.0 \mathrm{~Hz} ; \mathrm{H}-10, \mathrm{Me}-9)$. HRTOF-MS (-): $m / z 250.1491$ (Calcd for $\mathrm{C}_{11} \mathrm{H}_{24} \mathrm{O}_{3} \mathrm{NS}: 250.1482$ ).
8-Methylnonyl Sulfamate (12) White waxy solid. ${ }^{1} \mathrm{H}-\mathrm{NMR}(400 \mathrm{MHz}$, $\left.\mathrm{CD}_{3} \mathrm{OD}\right) \delta: 3.01(2 \mathrm{H}, \mathrm{t}, J=7.0 \mathrm{~Hz} ; \mathrm{H}-1), 1.58(3 \mathrm{H}, \mathrm{m} ; \mathrm{H}-2,8), 1.34(8 \mathrm{H}, \mathrm{en}-$ velop; $\mathrm{H}-3,4,5,6), 1.23(2 \mathrm{H}, \mathrm{m}$; H-7), $0.92(6 \mathrm{H}, \mathrm{d}, J=7.0 \mathrm{~Hz}$; H-9, Me-8). HR-FAB-MS (-): $m / z 236.1344$ (Calcd for $\mathrm{C}_{10} \mathrm{H}_{22} \mathrm{O}_{3} \mathrm{NS}: 236.1320$ ).

7-Methyloctyl Sulfamate (13) White waxy solid. ${ }^{1} \mathrm{H}-\mathrm{NMR}\left(\mathrm{CD}_{3} \mathrm{OD}\right)$ $\delta: 3.01(2 \mathrm{H}, \mathrm{t}, J=7.0 \mathrm{~Hz} ; \mathrm{H}-1), 1.52-1.63(3 \mathrm{H}, \mathrm{m} ; \mathrm{H}-2,7), 1.41-1.30$ (6H, m; H-3, 4, 5), 1.24 (2H, m; H-6), $0.92(6 \mathrm{H}, \mathrm{d}, J=7.0 \mathrm{~Hz}$; H-8, Me-7). ${ }^{13} \mathrm{C}-\mathrm{NMR}\left(\mathrm{CD}_{3} \mathrm{OD}\right) \delta: 45.0(\mathrm{C}-1), 40.2(\mathrm{C}-6), 30.8(\mathrm{C}-2,4), 29.2(\mathrm{C}-7)$, 28.5 (C-5), 28.3 (C-3), 23.0 (C-8, Me-7). HR-FAB-MS (-): $m / z 222.1178$ (Calcd for $\mathrm{C}_{9} \mathrm{H}_{20} \mathrm{O}_{3} \mathrm{NS}: 222.1164$ ).

\section{References}

1) Hessen D. O., van Donk E., Hydrobiologia, 127, 129-140 (1993).

2) Lampert W., Rothhaupt K. O., von Elert E., Limnol. Oceanogr., 39, 1543-1550 (1994).

3) von Elert E., Franck A., J. Plankton Res., 21, 789-804 (1999).

4) Wiltshire K. H., Lampert W., Limnol. Oceanogr., 44, 1894-1903 (1999).

5) Kaler V. L., Bulko O. P., Reshetnikov V. N., Galkovskaya G. A. Russ. J. Plant Phys., 47, 698-705 (2000).

6) von Elert E., Verh. Int. Ver. Theor. Angew. Limnol., 27, 2128-2131 (2000).

7) Lürling M., von Elert E., Limnol. Oceanogr., 46, 1809-1813 (2001).

8) van Holthoon F. L., van Beek T. A., Lürling M., van Donk E., De Groot A., Hydrobiologia, 491, 241-254 (2003).

9) Lürling M., Ann. Limnol.-Int. J. Limnol., 39, 85-101 (2003).

10) Yasumoto K., Nishigami A., Yasumoto M., Kasai F., Okada Y., Kusumi T., Ooi T., Tetrahedron Lett., 46, 4765-4767 (2005).

11) Yasumoto K., Nishigami A., Kasai F., Kusumi T., Ooi T., Chem. Pharm. Bull., 54, 271-274 (2006).

12) Tsukamoto S., Kato H., Hirota H., Fusetani N., J. Nat. Prod., 57, 1606-1609 (1994).

13) Nofre C., Pautet F., Bull. Chem. Soc. Fr., 1975(3-4, Pt. 2), 686-688 (1975). 